\title{
Genomic sequence analyses of classical and non-classical lamprey progesterone receptor genes and the inference of homologous gene evolution in metazoans
}

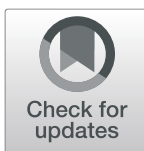

Jianfeng Ren ${ }^{1,3,4 \dagger}$, Yu-Wen Chung-Davidson ${ }^{2+}$, Liang Jia ${ }^{1}$ and Weiming $\mathrm{Li}^{2^{*}}$

\begin{abstract}
Background: Nuclear progesterone receptor (nPR) is an evolutionary innovation in vertebrates that mediates genomic responses to progesterone. Vertebrates also respond to progesterone via membrane progesterone receptors (mPRs) or membrane associated progesterone receptors (MAPRs) through rapid nongenomic mechanisms. Lampreys are extant agnathan vertebrates, residing at the evolutionary juncture where vertebrates diverged from invertebrates. A survey of the progesterone receptor (PR) gene sequences in lamprey genomes would inform PR gene evolutionary events during the transition from invertebrates to vertebrates.

Results: In this study, we annotated sequences of one $\mathrm{nPR}$, four mPR $(\beta, \gamma, \delta$ and $\varepsilon$ ) and four MAPR genes from genomes of two lamprey species (Petromyzon marinus and Lethenteron japonicum). To infer the origin and evolutionary history of PR genes, we constructed phylogenetic trees of PR homologous sequences across representative species of metazoans. Phylogenetic analyses revealed that the mPRy gene first appeared in non-bilaterians, and the mPR $\beta$ gene likely arose from a duplication of mPRy. On the other hand, the mPRy gene gave rise to the $\mathrm{mPR} \delta$ and $\varepsilon$ genes much later in the vertebrate lineage. In addition, the mPRa gene first appeared in cartilaginous fishes, likely derived from duplication of mPR $\beta$ after the agnathan-gnathostome divergence. All known MAPR genes were present in the lamprey genomes. Progesterone receptor membrane component 1 (PGRMC1), neudesin and neuferricin genes probably evolved in parallel in non-bilaterians, whereas two copies of PGRMC genes probably derived from duplication of ancestral PGRMC1 sequence and appeared before the speciation of lampreys.
\end{abstract}

Conclusions: Non-classical mPR and MAPR genes first evolved in non-bilaterians and classical nPR genes evolved later in basal vertebrates. Sequence repertoires for membrane progesterone receptor genes in vertebrates likely originated from an ancestral metazoan sequence and expanded via several duplication events.

Keywords: Nuclear progesterone receptor, Membrane progesterone receptor, Membrane associated progesterone receptor, Lamprey, Metazoan, Evolution

\footnotetext{
* Correspondence: liweim@msu.edu

${ }^{\dagger}$ Jianfeng Ren and Yu-Wen Chung-Davidson contributed equally to this

work.

${ }^{2}$ Department of Fisheries and Wildlife, Michigan State University, East

Lansing, Ml 48824, USA

Full list of author information is available at the end of the article
}

(c) The Author(s). 2019 Open Access This article is distributed under the terms of the Creative Commons Attribution 4.0 International License (http://creativecommons.org/licenses/by/4.0/), which permits unrestricted use, distribution, and reproduction in any medium, provided you give appropriate credit to the original author(s) and the source, provide a link to the Creative Commons license, and indicate if changes were made. The Creative Commons Public Domain Dedication waiver (http://creativecommons.org/publicdomain/zero/1.0/) applies to the data made available in this article, unless otherwise stated. 


\section{Background}

Progesterone $\left(\mathrm{P}_{4}\right)$ is one of the first discovered steroid hormones with known functions and subsequently pursued as a drug target [1]. It was initially discovered as a sex hormone, and later found to have broader effects, ranging from inhibition of apoptosis to regulation of cholesterol biosynthesis and axon guidance [2, 3]. Classical studies of $\mathrm{P}_{4}$ signaling have been focused on $\mathrm{nPR}$, a $\mathrm{P}_{4}$-activated transcription factor that directly regulates gene expression. More recently, $\mathrm{P}_{4}$ signaling has been noted for its role in modulating diverse neural processes such as cognitive functions and emotions $[4,5]$, neurogenesis [6, 7], neuroinflammation [8], neuroprotection and neuroplasticity [9-11]. It is now recognized that $P_{4}$ acts through both classical nPR that elicits slower genomic responses, and the non-classical membrane receptors that exert fast-acting non-genomic responses [12].

Non-classical PRs consist of mPRs [13] and MAPRs [14]. The mPRs are G-protein coupled receptors (GPCRs) that belong to Class II progestin and adipoQ receptor (PAQR) family, including $\mathrm{mPR} \alpha$ (PAQR7), mPR $\beta$ (PAQR8), mPR $\gamma$ (PAQR5), mPR $\delta$ (PAQR6), and $\mathrm{mPR} \varepsilon$ (PAQR9) [13]. mPR $\alpha$ was first characterized and isolated from the membrane fractions of seatrout ovary [15]. Subsequently, $\mathrm{mPR} \alpha, \beta$ and $\gamma$ were isolated from human, mouse, pig and other vertebrates [16, 17], with highly specific $\mathrm{P}_{4}$ binding abilities $[13,16]$. The proteins encoded by $\operatorname{mPR} \alpha, \beta$ and $\gamma$ genes are typically coupled to a pertussis-sensitive inhibitory $G$ protein $\left(G_{i}\right)$ that inhibits adenylyl cyclase activity, resulting in a decrease in secondary messenger cAMP levels [18]. On the contrary, $\mathrm{mPR} \delta$ and $\varepsilon$ are coupled to a stimulatory $\mathrm{G}$ protein $\left(G_{s}\right)$ that activates adenylyl cyclase and increases cAMP levels [19]. It is now widely accepted that mPRs have specific and saturable high-affinity binding sites for $\mathrm{P}_{4}$ [19].

The MAPRs include PGRMC1 [2, 3], PGRMC2 [20], neudesin [21], and neuferricin [22]. PGRMC1 was first isolated from porcine liver cell membranes with high $\mathrm{P}_{4^{-}}$ binding affinity [23]. Recent studies showed that $\mathrm{P}_{4}$ binds to human PGRMC1 [24], which acts as an adaptor protein of $\mathrm{mPR}$ to form a mPR protein complex [25]. PGRMC2 is structurally similar to PGRMC1 and likely evolved from a common ancestor $[3,26]$. Neudesin (neudesin neurotrophic factor, NENF) was first characterized as a neurotrophic factor [21], whereas neuferricin (cytochrome b5 domain containing 2, CYB5D2) is structurally related to neudesin, with similar cytochrome b5 (cyt-b5)-like hemebinding domain [22]. Unlike PGRMC1 and PGRMC2, neudesin and neuferricin appear to be secretory proteins [22], with no $\mathrm{P}_{4}$-binding ability $[27,28]$. It remains unclear whether the other MAPR members are involved in formation of the $\mathrm{mPR}$ protein complex, or exhibit $\mathrm{P}_{4}$ binding ability as PGRMC1.
So far, nPR genes have only been found in vertebrates [29]. By contrast, an ortholog of PR exists in invertebrate cephalochordates (also known as lancelets or amphioxi) $[30,31]$, and DNA sequences homologous to $\mathrm{mPR}$ or MAPR genes are more widespread in invertebrates, bacteria and fungi [32-35]. The endogenous hormonal function of $\mathrm{P}_{4}$ via $\mathrm{nPR}$ in vertebrates likely evolved in parallel with the neuroendocrine hypothalamic-pituitary-gonadal axis [36]. On the other hand, the sporadic occurrence of progestins, their biosynthetic enzymes and functional receptors in invertebrates $[37,38]$, suggests that these mPRs or MAPRs were not yet co-opted to bind endogenous progestins, or they likely responded to exogenous progestins produced by other organisms equipped with a full suite of biosynthetic enzymes [39]. Regardless of their actual ligands, these homologous sequences provided the foundation for the evolution of vertebrate MPR or MAPR genes.

Lampreys represent the basal jawless vertebrate lineage that diverged from jawed vertebrates around 560 million years ago [40, 41]. Sea lamprey possess a nPR gene [29]. There is evidence of membrane progesterone-binding activity but no specific receptor proteins or genes have been identified in sea lamprey [42]. The release of the draft genomes of two lamprey species, sea lamprey Petromyzon marinus and Japanese lamprey Lethenteron japonicum [43, 44], makes viable a genomic survey for different PR genes and the results may shed light on PR gene evolution from invertebrates to vertebrates. In this study, we sought to identify PR genes in lamprey genomes and to investigate the origin and evolutionary history of homologous gene sequences in metazoans through phylogenetic analyses.

\section{Results}

\section{Characteristics of lamprey nPR gene sequence}

One $\mathrm{nPR}$ gene was identified in the sea lamprey and Japanese lamprey genomes. The transcript, coding DNA sequence (CDS), and predicted amino acid sequence are listed in Table 1 . The CDS region of sea lamprey $\mathrm{nPR}$ is $12 \mathrm{bp}$ longer than that of Japanese lamprey. The nucleotide and amino acid residue sequences are 96.7 and $98.0 \%$ identical between the sea lamprey and Japanese lamprey.

The lamprey nPR gene consisted of 8 exons and spanned 120,720 bp on the chromosome (Fig. 1a), consistent with those in human, mouse and zebrafish (Additional file 3). The 12 additional bp of the sea lamprey nPR gene were located in the fourth exon of the CDS region. Protein domain structure analysis showed that the predicted nPR protein contained two highly-conserved domains, the DNA-binding domain (DBD) and the ligandbinding domain (LBD) (Fig. 1b). The DBD consisted of approximately 70 amino acids (55-124) with two C4-type zinc fingers, responsible for the interaction between the 
Table 1 Detailed information for nPR, mPR and MAPR gene families identified in lampreys

\begin{tabular}{|c|c|c|c|c|c|c|c|c|c|c|}
\hline \multirow[t]{2}{*}{ Gene/transcript name } & \multicolumn{5}{|l|}{ Sea lamprey } & \multicolumn{3}{|c|}{ Japanese lamprey } & \multirow[t]{2}{*}{ Domains } & \multirow[t]{2}{*}{ Reference $^{\mathrm{b}}$ (aa) } \\
\hline & $\begin{array}{l}\text { GenBank } \\
\text { accession No. }\end{array}$ & $\begin{array}{l}\text { Transcript } \\
\text { (bp) }\end{array}$ & $\begin{array}{l}\text { CDS } \\
\text { (bp) }\end{array}$ & $\begin{array}{l}\text { Protein } \\
\text { (aa) }\end{array}$ & $\begin{array}{l}\text { CDS } \\
\text { status }^{\mathrm{a}}\end{array}$ & $\begin{array}{l}\mathrm{CDS} \\
\text { (bp) }\end{array}$ & $\begin{array}{l}\text { Protein } \\
\text { (aa) }\end{array}$ & $\begin{array}{l}\text { CDS } \\
\text { status }\end{array}$ & & \\
\hline $\mathrm{nPR}$ & KT970662 & 1967 & 1341 & 446 & $C$ & 1329 & 442 & $C$ & $\mathrm{DBD} / \mathrm{LBD}$ & 933 \\
\hline $\mathrm{mPR} \beta$ isoform 1 & KT970648 & 2016 & 1077 & 358 & C & 1077 & 358 & C & TM/HlyllI & 354 \\
\hline $\mathrm{mPR} \beta$ isoform 2 & KT970649 & 2038 & 1077 & 358 & C & - & - & - & TM/HlyllI & 354 \\
\hline $\mathrm{mPR} \beta$ isoform3 & KT970650 & 2324 & 1077 & 358 & C & - & - & - & TM/HlyllI & 354 \\
\hline $\mathrm{mPR} \beta$ isoform 4 & KT970651 & 2593 & 1077 & 358 & C & - & - & - & TM/HlyllI & 354 \\
\hline $\mathrm{mPR} \gamma$ & KT970652 & 1621 & 1089 & 362 & C & 1080 & 359 & C & TM/HlyllI & 330 \\
\hline mPRS isoform 1 & KT970653 & 1984 & 1029 & 342 & C & 1029 & 342 & C & TM/HlyllI & 341 \\
\hline $\mathrm{mPR} \delta$ isoform2 & KT970654 & 1273 & 873 & 290 & C & - & - & - & TM/HlyllI & 341 \\
\hline $\mathrm{mPR} \delta$ isoform3 & KT970655 & 1786 & 873 & 290 & C & - & - & - & TM/Hly|lI & 341 \\
\hline $\mathrm{mPR} \delta$ isoform4 & KT970656 & 2236 & 873 & 290 & C & - & - & - & TM/HlyllI & 341 \\
\hline mPRe & KT970657 & 882 & 822 & 273 & $P$ & 1023 & 340 & C & TM/HlyllI & 377 \\
\hline PGRMC1 & KT970658 & 1485 & 552 & 183 & C & 549 & 182 & C & TM/Cyt-b5 & 195 \\
\hline PGRMC2 & KT970659 & 689 & 417 & 138 & $P$ & 396 & 131 & $P$ & TM/Cyt-b5 & 247 \\
\hline neudesin & KT970660 & 609 & 525 & 174 & C & 525 & 174 & C & SP/Cytb-b5 & 172 \\
\hline neuferricin & KT970661 & 1592 & 840 & 279 & C & 849 & 282 & C & SP/Cytb-b5 & 264 \\
\hline
\end{tabular}

${ }^{\text {a }} \mathrm{P}$ indicates partial sequence, $\mathrm{C}$ indicates complete sequence. ${ }^{\mathrm{b}}$ Reference indicates the length of the proteins in human

hormone-receptor complex and the hormone response element, located within the promoter region of the target genes [45]. The LBD was located at the carboxyl terminus (216-404), containing sub-regions for ligand binding, dimerization and transcriptional regulation [46].

Protein motif analyses revealed that the lamprey nPR protein contained Erk1 kinase and Itk Src homolog 2 (SH2) domains that were not found in lamprey mPR or MAPR sequences (Table 2, Additional file 4). Nonetheless, similar domains for $\mathrm{SH} 2$ or $\mathrm{SH} 3$ interactions, kinase or kinase-binding were present in MPR or MAPR sequences. These findings indicate that mPRs, MAPRs and $\mathrm{nPR}$ may potentially recognize and interact with similar proteins in lampreys.

\section{Phylogenetic analyses of nPR genes and metazoan ER/ ERR/AncSR genes}

Since the nPR gene is thought to have derived from an ancestral ER gene $[29,47]$, we performed phylogenetic analysis of nPR, ER and ERR genes from representative metazoan groups to infer the evolutionary position of the lamprey nPR gene. ERR shared a common ancestor with ER [47], and was selected as the out group for the phylogenetic analysis. As expected, nPR genes were only found in vertebrates, and each vertebrate species possessed only one copy of the nPR gene. The phylogenetic trees from both $\mathrm{NJ}$ and ML methods were clustered into nPR, ER and ERR clades with the placozoan ERR gene at the base (Fig. 2 and Additional file 5). The lancelet ancestral progesterone/corticoid receptor (the same sequence as AncSR2 in [29]) was at the base of the nPR clade [47]. In general, the selected nPR, ER, and ERR genes were clustered in a pattern consistent with the phylogenetic relationship of the species.

\section{Characteristics of lamprey mPR genes}

Four lamprey $\mathrm{mPR}$ genes $(\mathrm{mPR} \beta, \gamma, \delta$, and $\varepsilon)$ were located in different scaffolds (Additional file 6) in both sea lamprey and Japanese lamprey genomes (Table 1). All genes contained full-length CDSs except sea lamprey $\operatorname{mPR} \varepsilon$ (Table 1). No ortholog of the gnathostome $\mathrm{mPR} \alpha$ gene was found in either lamprey genome assembly.

Four mPR $\beta$ transcript isoforms were identified in the sea lamprey (Additional file 7), with lengths varying from 2016 to $2593 \mathrm{bp}$ due to variations at the $5^{\prime}$ untranslated region (5'UTR). The CDSs were identical (1077 bp) and encoded 358 amino acids. Contrary to the $\mathrm{mPR} \beta$ CDS transcribed from a single exon in human, mouse and zebrafish (Additional file 3), lamprey $\mathrm{mPR} \beta$ CDS was transcribed from four exons and the gene spanned $6749 \mathrm{bp}$ on the chromosome (Fig. 1a). However, the predicted lamprey $\mathrm{mPR} \beta$ protein length was close to that of human, mouse and zebrafish.

The predicted sea lamprey mPR $\gamma$ protein (362 amino acids) was 3 amino acids longer than that of the Japanese lamprey, and slightly longer than those in human, mouse and zebrafish. Lamprey $\mathrm{mPR} \gamma \mathrm{CDS}$ was transcribed from eight exons, similar to those in zebrafish but in contrast to the seven exons of human and mouse $\mathrm{mPR} \gamma$ (Additional file 3). Sea lamprey $\mathrm{mPR} \gamma$ gene was 


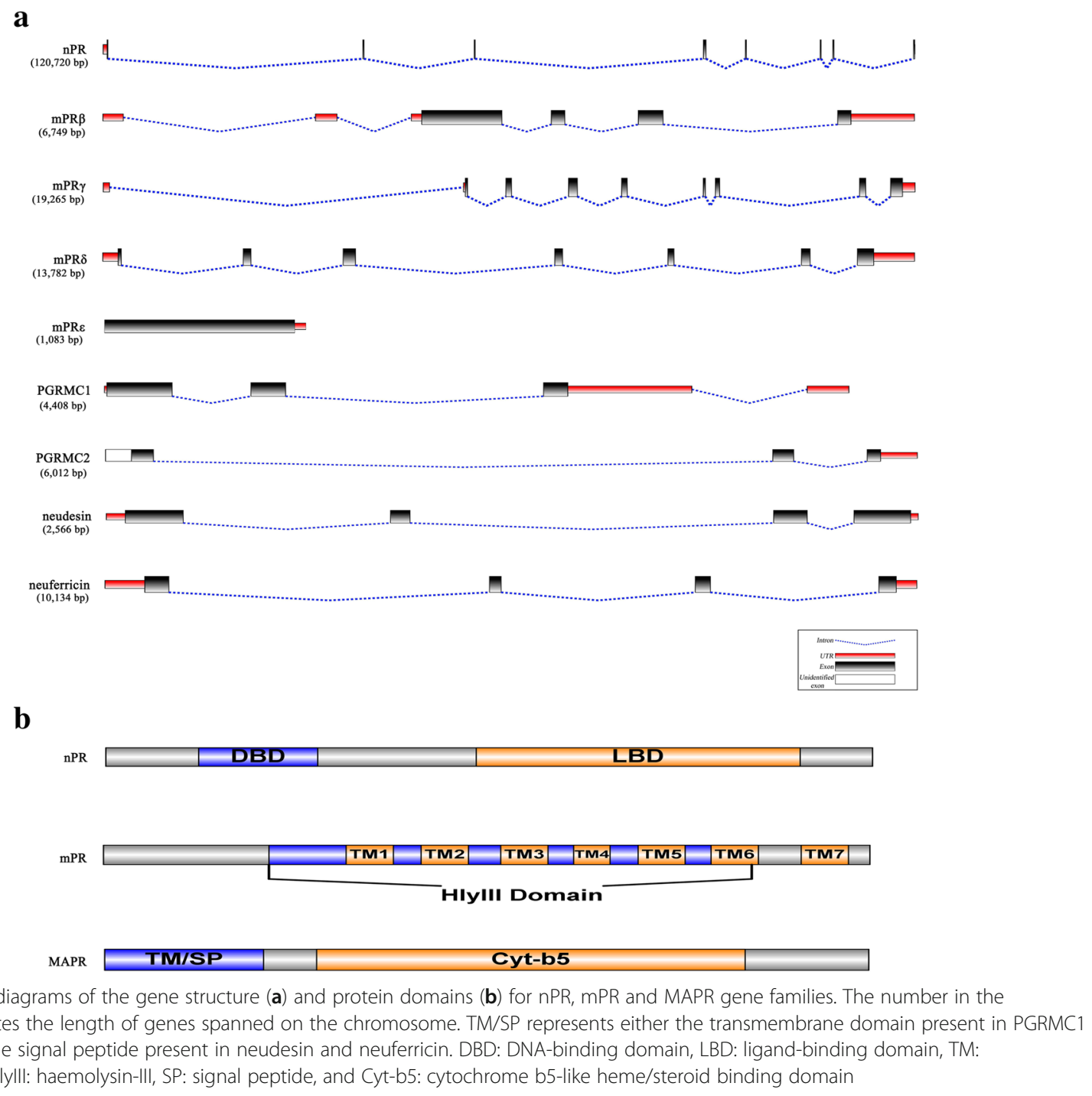

the longest among the mPR genes, spanning $19,265 \mathrm{bp}$ on the chromosome (Fig. 1a).

Four $\mathrm{mPR} \delta$ transcript isoforms were identified in the sea lamprey, of which isoforms 2,3 , and 4 possessed the same CDS but differed in the untranslated regions (Table 1 and Additional file 8). The gene sequence for isoform 1 spanned 13,782 bp on the chromosome (Fig. 1a). The structure of the CDS and the amino acid length of isoform 1 were similar to the dominant mPR $\delta$ isoform in human, mouse and zebrafish (Additional file 3). Two lamprey $\mathrm{mPR} \delta$ protein isoforms contained 342 and 290 amino acids, with different amino acid residues at the $\mathrm{C}$-terminus.

The Japanese lamprey $\mathrm{mPR} \varepsilon$ sequence contained a full length CDS while the sea lamprey CDS was incomplete, lacking 67 amino acid residues at the $\mathrm{N}$ terminus (Table 1). Both CDSs were transcribed from a single exon gene, similar to the gene of mPRe in human and mouse, but differed from that of zebrafish in which two exons are separated by an $89 \mathrm{bp}$ intron (Additional file 3).

In general, the predicted lamprey mPR proteins contained 340-359 amino acid residues. These receptors all contained seven trans-membrane (7TM) domains and one highly conserved haemolysin-III (Hly III)-related domain (Fig. 1b). Protein motif analyses revealed that lamprey $\mathrm{mPR}$ proteins contained various $\mathrm{SH} 2, \mathrm{SH} 3$, kinase or kinase-binding domains (Table 2). For example, $\operatorname{mPR} \beta$ contained an insulin receptor kinase domain that was not found in other lamprey PRs, and $\mathrm{PIP}_{3}$ binding domain was only found in mPR (Table 2).

\section{Phylogenetic analyses of metazoan mPR sequences}

The $\mathrm{mPR}$ gene family expanded in metazoans and increased from one $(\mathrm{mPR} \gamma)$ to five family members $(\mathrm{mPR} \alpha, \beta, \gamma, \delta$ and $\varepsilon$; Table 3$)$. The phylogenetic analyses of $\mathrm{mPR}$ genes from representative species using both $\mathrm{N}$ ) 
Table 2 Motif frequency from lamprey progesterone receptor protein sequences

\begin{tabular}{|c|c|c|c|c|c|c|c|c|c|c|}
\hline Motif group & Motif name & $\mathrm{mPR} \beta$ & mPRy & $\mathrm{mPR} \delta$ & $\mathrm{mPR} \varepsilon$ & PGRMC1 & PGRMC2 & neudesin & neuferricin & $\mathrm{nPR}$ \\
\hline \multirow{3}{*}{$\begin{array}{l}\text { Acidophilic } \\
\text { Ser/Thr kinase }\end{array}$} & Casein kinase 1 & 0 & 0 & 0 & 0 & $1^{\mathrm{a}}$ & 0 & 0 & 0 & 0 \\
\hline & Casein kinase 2 & 0 & 0 & 0 & 0 & 2 & $1^{\mathrm{a}}$ & 0 & 0 & 0 \\
\hline & GSK3 & 2 & 0 & 0 & 0 & 0 & 0 & 0 & 0 & 0 \\
\hline \multirow{8}{*}{$\begin{array}{l}\text { Basophilic } \\
\text { Ser/Thr kinase }\end{array}$} & Akt kinase & 0 & 0 & 0 & 0 & 0 & 1 & 0 & 1 & 1 \\
\hline & AMP kinase & $1^{\mathrm{a}}$ & 0 & 2 & 0 & 0 & 0 & 0 & 0 & 1 \\
\hline & Calmodulin dependent kinase 2 & 0 & 0 & 0 & 0 & 0 & 0 & 0 & 1 & 0 \\
\hline & Clk2 kinase & 1 & 0 & 0 & 1 & 0 & 0 & 0 & 0 & 0 \\
\hline & $\mathrm{PKC} \delta$ & 1 & 1 & 1 & 0 & 0 & 0 & 0 & 0 & 0 \\
\hline & $\mathrm{PKC}_{\varepsilon}$ & 0 & 0 & 0 & 0 & 0 & 0 & $1^{\mathrm{a}}$ & 0 & 1 \\
\hline & $\mathrm{PKC}_{\zeta}$ & 2 & 0 & 0 & 1 & 0 & 0 & 0 & 0 & 0 \\
\hline & $\mathrm{PKC}_{\mu}$ & 0 & 0 & 1 & 0 & 0 & 0 & 0 & 0 & 1 \\
\hline \multirow[t]{2}{*}{ DNA damage kinase } & DNA PK & 0 & 0 & 0 & 0 & 0 & 2 & $1^{\mathrm{a}}$ & 0 & 2 \\
\hline & ATM kinase & 0 & 0 & 1 & 0 & 0 & 0 & $1^{\mathrm{a}}$ & 0 & $1^{a}$ \\
\hline \multirow[t]{3}{*}{ Kinase binding site } & Erk1 binding & $1^{\mathrm{a}}$ & $2\left(1^{a}\right)$ & 2 & 0 & 0 & 0 & 0 & 0 & 0 \\
\hline & Erk D-domain & 2 & 0 & 0 & 1 & 0 & 1 & 1 & 2 & 0 \\
\hline & PDK1 binding & 1 & 1 & 0 & $2\left(1^{\mathrm{a}}\right)$ & 0 & 0 & 0 & 1 & 2 \\
\hline Lipid binding & $\mathrm{PIP}_{3}$ binding $\mathrm{PH}$ & 0 & 2 & 0 & 0 & 0 & 0 & 0 & 0 & 0 \\
\hline Phospho-Ser/Thr binding & 14-3-3 mode 1 & 0 & 1 & 0 & 0 & 0 & 0 & 0 & 0 & 1 \\
\hline Proline-dependent Ser/Thr kinase & Erk1 kinase & 0 & 0 & 0 & 0 & 0 & 0 & 0 & 0 & $1^{\mathrm{a}}$ \\
\hline \multirow[t]{6}{*}{ Src homology 2 (SH2) } & $\mathrm{Abl} \mathrm{SH} 2$ & 0 & 1 & 0 & 0 & 0 & 0 & 0 & 0 & 0 \\
\hline & Grb2 SH2 & 0 & 0 & 0 & 1 & 0 & 0 & 0 & 0 & 0 \\
\hline & Itk SH2 & 0 & 0 & 0 & 0 & 0 & 0 & 0 & 0 & 1 \\
\hline & PLCY C-terminal SH2 & 0 & 1 & 0 & 0 & 0 & 0 & 0 & 0 & 0 \\
\hline & Shc SH2 & 0 & 0 & 0 & 0 & 0 & 1 & 0 & 0 & 1 \\
\hline & SHIP SH2 & 0 & 0 & 0 & 0 & 0 & 1 & 0 & 0 & 0 \\
\hline \multirow[t]{4}{*}{ Src homology 3 (SH3) } & Cbl-associated protein C-SH3 & $1^{\mathrm{a}}$ & 0 & 0 & 0 & 0 & 0 & 0 & 0 & 0 \\
\hline & Grb2 SH3 & 0 & 0 & 0 & 0 & 0 & 0 & 0 & 1 & 0 \\
\hline & Itk SH3 & 1 & 0 & 0 & 0 & 0 & 0 & 0 & 0 & 0 \\
\hline & p85 SH3 mode 2 & 1 & 0 & 0 & 0 & 0 & 0 & 0 & 0 & 0 \\
\hline \multirow[t]{4}{*}{ Tyrosine kinase } & Abl kinase & 0 & 0 & 0 & 0 & 1 & 0 & 0 & 0 & 0 \\
\hline & Insulin receptor kinase & 1 & 0 & 0 & 0 & 0 & 0 & 0 & 0 & 0 \\
\hline & Lck kinase & 0 & 0 & 0 & 0 & 1 & 1 & 0 & 0 & 1 \\
\hline & Src kinase & 0 & 0 & 0 & 0 & 0 & 1 & 0 & 0 & 1 \\
\hline
\end{tabular}

Protein motifs were predicted using the Scansite cell signaling interactions prediction "MotifScan" module (https://scansite4.mit.edu/4.0/\#scanProtein) under medium stringency setting. ${ }^{a}$ Motifs that were also predicted under high stringency setting. Motif sequences are listed in Additional file 4

and ML methods demonstrated the evolutionary relationships among these five genes in metazoans (Fig. 3 and Additional file 9). Placozoan and sea anemone $\mathrm{mPR} \gamma$ genes were positioned at the base of the metazoan lineage. The phylogenetic trees formed three subclades (from bottom to top): vertebrate $\mathrm{mPR} \varepsilon$, sister groups of bilaterian $\mathrm{mPR} \gamma$ and vertebrate $\mathrm{mPR} \delta$, and $\mathrm{mPR} \beta$-like genes including mPR $\alpha$ and $\beta$ (Fig. 3 and Additional file 9). Ancestral $\mathrm{mPR} \gamma$ genes gave rise to $\mathrm{mPR} \beta$ and $\mathrm{mPR} \gamma$ genes early in bilaterian evolution. On the other hand, the ancestral $\mathrm{mPR} \beta$ gene further diverged into the "sister" genes
$\mathrm{mPR} \alpha$ and $\mathrm{mPR} \beta$, indicating that $\mathrm{mPR} \alpha$ separated from $\operatorname{mPR} \beta$ gene duplication after the divergence of the agnathans and gnathostomes (Fig. 3 and Additional file 9). In addition, vertebrate $\mathrm{mPR} \delta$ and $\mathrm{mPR} \gamma$ genes were clustered together in the phylogenetic tree excluding the lamprey $\mathrm{mPR} \gamma$ gene, indicating that the ancestral $\mathrm{mPR} \gamma$ gene divided into $\mathrm{mPR} \gamma$ and $\delta$ before the speciation of vertebrates (Fig. 3; also see Table 3). Unfortunately, the origin of the $\mathrm{mPR} \varepsilon$ gene was not properly resolved in the phylogenetic trees. Vertebrate $\mathrm{mPR} \varepsilon$ genes were clustered with $\mathrm{mPR} \gamma$ sequences of early-branching animals, probably 


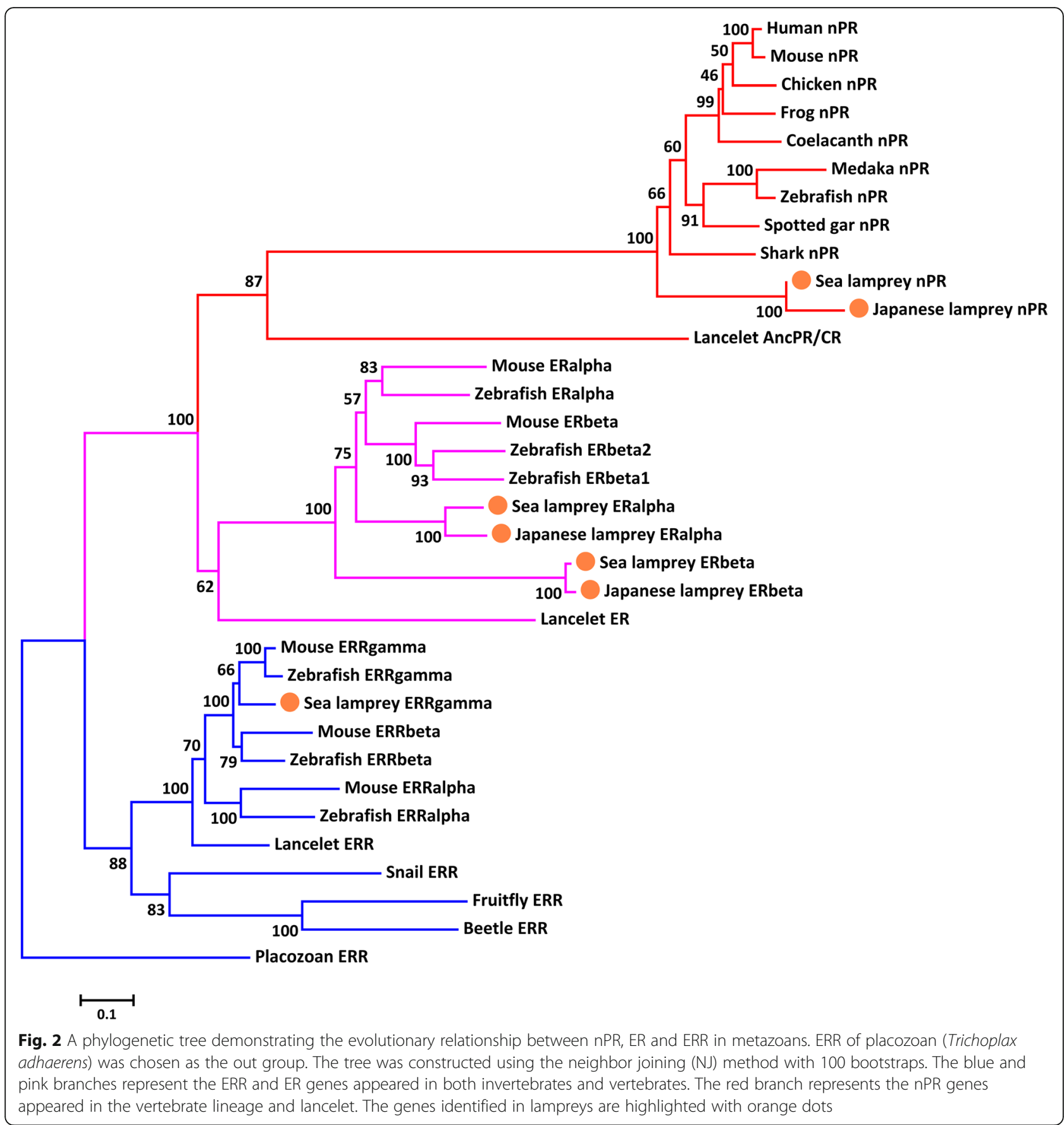

resulting from random clustering during phylogenetic construction. Therefore, the $\mathrm{mPR} \varepsilon$ gene likely originated from the mPRy gene in eumetazoa and was lost in invertebrates, or alternatively arose from gene duplication of $\mathrm{mPR} \gamma$ prior to vertebrate radiation.

Results of protein motif analyses were consistent with those from phylogenetic analyses (Table 2). Both mPR $\beta$ and $\mathrm{mPR} \gamma$ proteins contained basophilic serine/threonine kinase and kinase binding domains. However, $\mathrm{mPR} \beta$ also acquired $\mathrm{SH} 3$ and tyrosine kinase domains, whereas $\mathrm{mPR} \gamma$ acquired $\mathrm{PIP}_{3}$-binding and $\mathrm{SH} 2$ domains, and $\mathrm{mPR} \delta$ acquired extra DNA damage kinase domains (Table 2).

\section{Characteristics of lamprey MAPR genes}

Sequences of MAPR gene family (PGRMC1, PGRMC2, neudesin, and neuferricin) were located in different scaffolds (Additional file 6) of sea lamprey and Japanese lamprey genomes. All identified lamprey MAPR genes contained full-length CDSs except PGRMC2. Sea 
Table 3 Gene number for nPR, mPR and MAPR gene families identified in representative species

\begin{tabular}{|c|c|c|c|c|c|c|c|c|c|c|c|c|}
\hline Taxonomy & Common name & Scientific name & $\mathrm{mPRa}$ & $\mathrm{mPR \beta}$ & $\mathrm{mPRy}$ & $\mathrm{mPR} \delta$ & mPRE & PGRMC1 & PGRMC2 & neudesin & neuferricin & $\mathrm{nPR}$ \\
\hline Mammalia & Human & Homo sapiens & 1 & 1 & 1 & 1 & 1 & 1 & 1 & 1 & 1 & 1 \\
\hline Mammalia & Mouse & Mus musculus & 1 & 1 & 1 & 1 & 1 & 1 & 1 & 1 & 1 & 1 \\
\hline Aves & Chicken & Gallus gallus & 1 & 1 & 1 & 0 & 1 & 1 & 1 & 1 & 1 & 1 \\
\hline Reptilia & Lizard & Anolis carolinensis & 1 & 0 & 1 & 0 & 0 & 1 & 1 & 1 & 0 & 1 \\
\hline Amphibia & Frog & Xenopus tropicalis & 0 & 1 & 1 & 1 & 1 & 1 & 1 & 1 & 1 & 1 \\
\hline Osteichthyes & Coelacanth & Latimeria chalumnae & 1 & 1 & 1 & 1 & 1 & 1 & 2 & 1 & 1 & 1 \\
\hline Osteichthyes & Takifugu & Takifugu rubripes & 3 & 2 & 1 & 1 & 1 & 1 & 1 & 1 & 1 & 1 \\
\hline Osteichthyes & Medaka & Oryzias latipes & 2 & 1 & 1 & 1 & 1 & 1 & 1 & 1 & 1 & 1 \\
\hline Osteichthyes & Zebrafish & Danio rerio & 2 & 1 & 2 & 1 & 1 & 1 & 1 & 1 & 1 & 1 \\
\hline Osteichthyes & Spotted gar & Lepisosteus oculatus & 2 & 1 & 1 & 1 & 1 & 1 & 1 & 1 & 1 & 1 \\
\hline Chondrichthyes & Elephant shark & Callorhinchus milii & 1 & 0 & 1 & 0 & 0 & 1 & 1 & 1 & 1 & 1 \\
\hline Agnatha & Sea lamprey & Petromyzon marinus & 0 & 1 & 1 & 1 & 1 & 1 & 1 & 1 & 1 & 1 \\
\hline Agnatha & Japanese lamprey & Lethenteron japonicum & 0 & 1 & 1 & 1 & 1 & 1 & 1 & 1 & 1 & 1 \\
\hline Urochordata & $\begin{array}{l}\text { Transparent Sea } \\
\text { squirt }\end{array}$ & Ciona savignyi & 0 & 2 & 2 & 0 & 0 & 0 & 0 & 0 & 1 & 0 \\
\hline Urochordata & Vase tunicate & Ciona intestinalis & 0 & 2 & 2 & 0 & 0 & 1 & 0 & 0 & 1 & 0 \\
\hline Cephalochordata & Florida lancelet & Branchiostoma floridae & 0 & 8 & 1 & 0 & 0 & 1 & 0 & 1 & 2 & 0 \\
\hline Hemichordata & Acorn worm & $\begin{array}{l}\text { Saccoglossus } \\
\text { kowalevskii }\end{array}$ & 0 & 1 & 2 & 0 & 0 & 1 & 0 & 1 & 1 & 0 \\
\hline Echinodermata & Purple sea urchin & $\begin{array}{l}\text { Strongylocentrotus } \\
\text { purpuratus }\end{array}$ & 0 & 1 & 3 & 0 & 0 & 1 & 0 & 1 & 2 & 0 \\
\hline Platyhelminthes & Blood fluke & Schistosoma mansoni & 0 & 0 & 1 & 0 & 0 & 1 & 0 & 0 & 0 & 0 \\
\hline Annelida & Polychaete worm & Capitella teleta & 0 & 2 & 2 & 0 & 0 & 3 & 0 & 1 & 1 & 0 \\
\hline Mollusca & Owl limpet & Lottia gigantea & 0 & 4 & 1 & 0 & 0 & 1 & 0 & 1 & 1 & 0 \\
\hline Mollusca & Pacific oyster & Crassostrea gigas & 0 & 3 & 1 & 0 & 0 & 1 & 0 & 0 & 1 & 0 \\
\hline Nematoda & Nematode & Caenorhabditis elegans & 0 & 1 & 0 & 0 & 0 & 1 & 0 & 0 & 1 & 0 \\
\hline Crustacea & Water flea & Daphnia pulex & 0 & 0 & 1 & 0 & 0 & 1 & 0 & 0 & 1 & 0 \\
\hline Insecta & Fruit fly & $\begin{array}{l}\text { Drosophila } \\
\text { melanogaster }\end{array}$ & 0 & 0 & 0 & 0 & 0 & 3 & 0 & 0 & 1 & 0 \\
\hline Insecta & Silkworm & Bombyx mori & 0 & 0 & 0 & 0 & 0 & 1 & 0 & 0 & 1 & 0 \\
\hline Cnidaria & $\begin{array}{l}\text { Starlet sea } \\
\text { anemone }\end{array}$ & Nematostella vectensis & 0 & 0 & 7 & 0 & 0 & 2 & 0 & 1 & 2 & 0 \\
\hline Placozoa & Placozoan & Trichoplax adhaerens & 0 & 0 & 3 & 0 & 0 & 1 & 0 & 0 & 1 & 0 \\
\hline Porifera & Sponge & $\begin{array}{l}\text { Amphimedon } \\
\text { queenslandica }\end{array}$ & 0 & 0 & 1 & 0 & 0 & 0 & 0 & 0 & 1 & 0 \\
\hline Protist & Choanoflagellate & Monosiga brevicollis & 0 & 0 & 0 & 0 & 0 & 1 & 0 & 0 & 1 & 0 \\
\hline
\end{tabular}

lamprey PGRMC1 gene spanned $4408 \mathrm{bp}$ on the chromosome, and the encoded protein was one amino acid longer than that of Japanese lamprey (Table 1). Lamprey PGRMC1 CDS was transcribed from three exons (Fig. 1a), and the predicted protein length was close to those in human, mouse, and zebrafish (Additional file 3).

Both lamprey PGRMC2 sequences contained incomplete CDSs. Sea lamprey PGRMC2 was longer than that of Japanese lamprey (Table 1). Both predicted proteins were truncated at the $\mathrm{N}$-terminus and were shorter than full-length PGRMC2 proteins in human, mouse and zebrafish. The structures of lamprey PGRMC2 CDSs were similar to those of human, mouse and zebrafish with three exons (Additional file 3), with the missing amino acid sequence encoded in the first exon region (Fig. 1a).

The sea lamprey neudesin gene spanned $2566 \mathrm{bp}$ and contained $5^{\prime}$ and 3' UTRs (Fig. 1a). The CDS encoded 174 amino acids transcribed from four exons in both lampreys, similar to their orthologs in human, mouse and zebrafish. On the contrary, sea lamprey neuferricin protein was 3 amino acids shorter than that of Japanese 


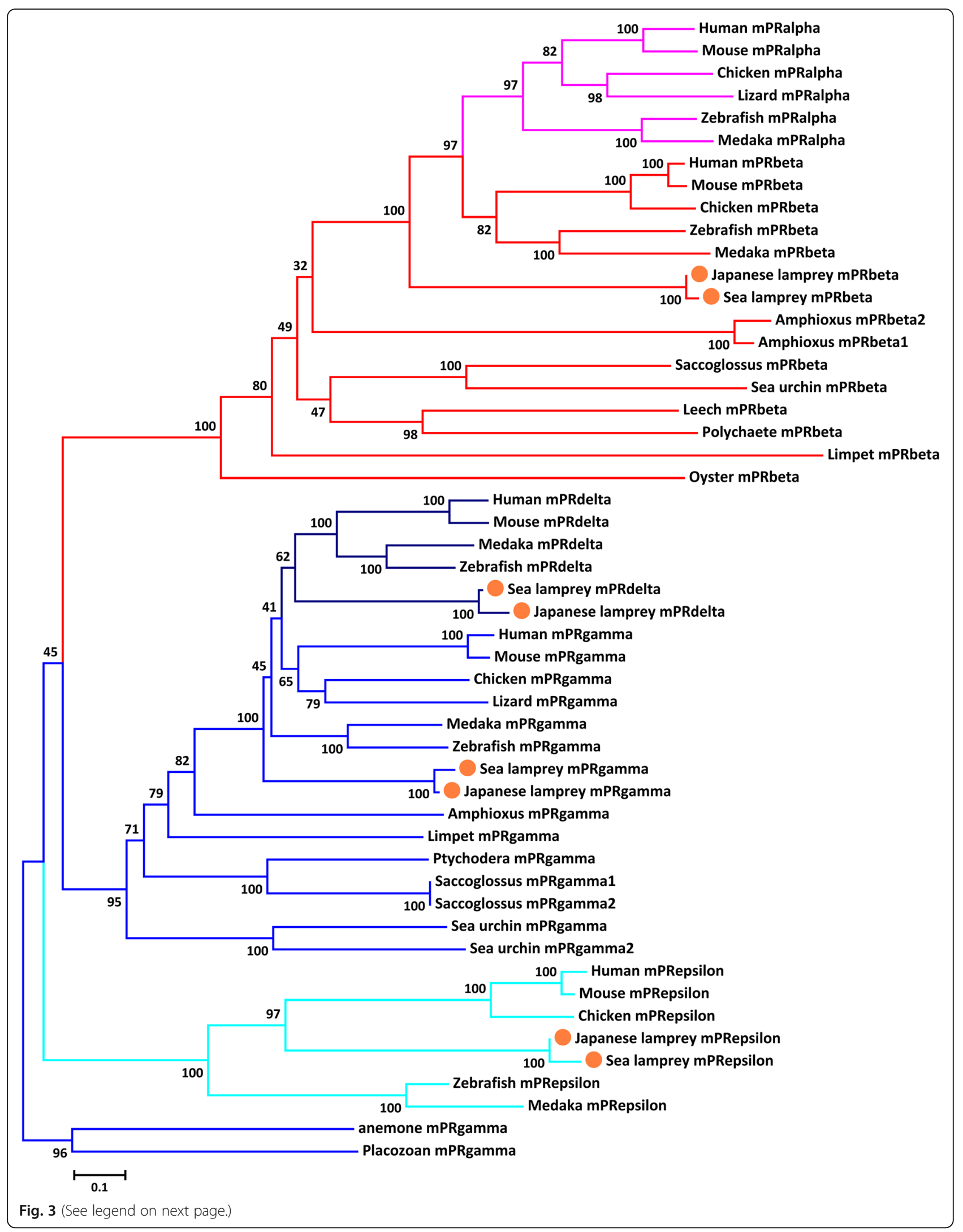


(See figure on previous page.)

Fig. 3 A phylogenetic tree demonstrating the evolutionary relationship among five members of mPR gene families in metazoans. The mPRy of placozoan and sea anemone were chosen as the out groups. The tree was constructed using the NJ method with 100 bootstraps. Different members of $\mathrm{mPR}$ gene family in metazoans are clustered and highlighted with different colors (pink: $\mathrm{mPRa}$; red: $\mathrm{mPR} \beta$; dark blue: $\mathrm{mPR \delta}$; blue: mPRy; light blue: $m P R \varepsilon)$. The genes identified in lampreys are indicated with orange dots

lamprey (Table 1). Both lamprey neuferricin CDSs were transcribed from four exons (similar to human, mouse and zebrafish CDSs), but the protein lengths were slightly longer (Additional file 3).

The MAPR proteins identified in lampreys were around 131-282 amino acids long, shorter than lamprey mPR proteins. The MAPR proteins contained either one transmembrane domain (PGRMC1 and PGRMC2) or a signal peptide (neudesin and neuferricin) at the $\mathrm{N}$ terminus, and a heme-binding domain (Cyt-b5) at the C-terminus (Fig. 1b). Protein motif analyses revealed that each MAPR protein contained unique domains, but also retained similar domains that might interact in overlapping signal transduction pathways. For example, neuferricin contained a calmodulin-dependent kinase 2 domain, PGRMC1 possessed an Abl kinase domain, and both PGRMC1 and 2 contained casein kinase and LSK kinase domains (Table 2).

\section{Phylogenetic analyses of metazoan MAPR sequences}

The phylogenetic trees of PGRMC1/2, neudesin and neuferricin were built separately due to their diverse

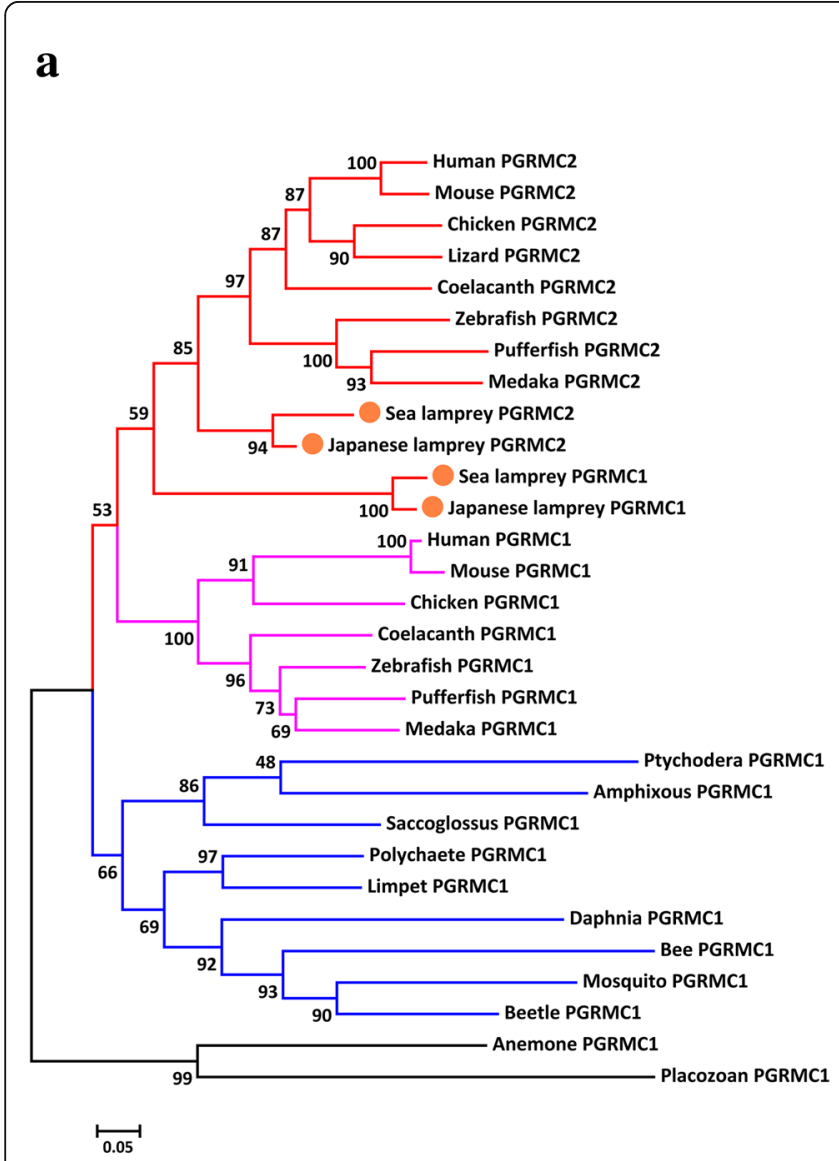

b

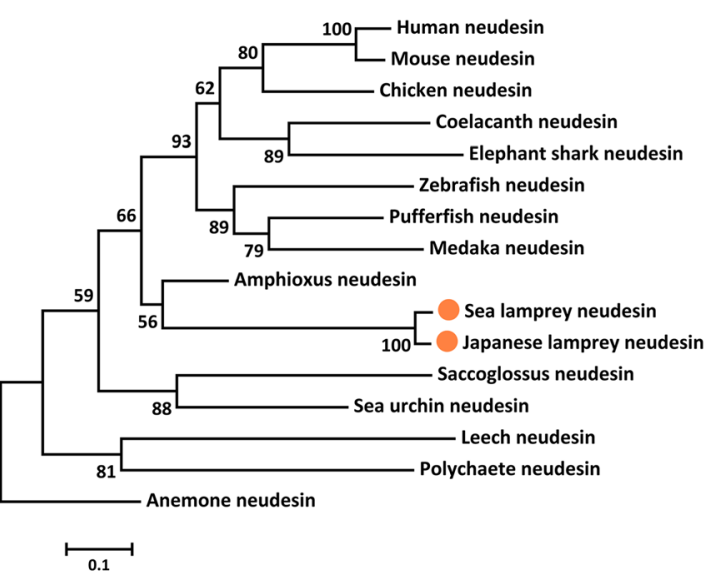

C

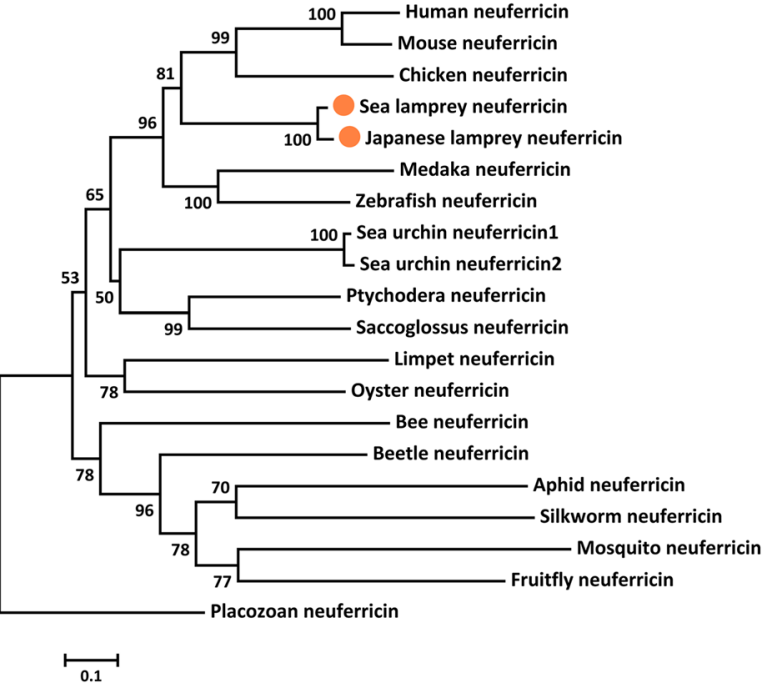

Fig. 4 The separated phylogenetic trees of PGRMC1/2 (a), neudesin (b), neuferricin (c) demonstrated the evolutionary relationship among each member of MAPR gene family in metazoans. The trees were constructed using the NJ method with 100 bootstraps. Different clades of PGRMC genes in metazoans are highlighted with different colors (red: vertebrate PGRMC2; pink: vertebrate PGRMC1; blue: invertebrate PGRMC1; black: PGRMC1 out groups). The MAPR genes identified in lampreys are indicated with orange dots 
amino acid sequences. In general, the topologies of the phylogenetic trees were consistent with evolutionary relationships among representative species with moderate to high bootstrap values (Fig. 4 and Additional file 10). The phylogenetic tree of PGRMC was clustered into an invertebrate PGRMC1 clade and a vertebrate PGRMC clade. The vertebrate PGRMC clade was further divided into PGRMC1 and PGRMC2 sister groups. However, lamprey PGRMC1 was always clustered with vertebrate PGRMC2 in both NJ and ML trees, probably due to incomplete lamprey PGRMC2 sequences (Fig. 4a and Additional file 10a). The PGRMC1 gene was identified in nearly all metazoan species examined, even in the closest known unicellular living relative of animals, choanoflagellate (Monosiga brevicollis) (Table 3 and Additional file 2). On the contrary, the PGRMC2 gene was only identified in vertebrates (Fig. 4a). These results indicated that two copies of PGRMC genes probably derived from duplication of ancestral PGRMC1 sequence and appeared before the speciation of agnathans.

The Neudesin gene was first identified in sea anemone (Cnidaria) and later found as a single copy in invertebrates and vertebrates (Table 3). However, the neudesin gene was not found in several protostomes such as platyhelminthes, nematodes, crustacean and insects (Table 3 and Additional file 2). Neuferricin genes were identified in all metazoan phyla examined except Platyhelminthes (Table 3 and Additional file 2). The lack of neudesin genes in these phyla may be due to incomplete genome assemblies or gene loss.

Protein motif analyses of lamprey MAPR proteins supported the conclusion from phylogenetic analyses that PGRMC2 may have derived from PGRMC1 since both contained acidophilic serine/threonine kinase and tyrosine kinase domains, and PGRMC2 further acquired DNA damage kinase, Erk-D and SH2 domains. Neudesin and neuferricin both contained basophilic kinase and Erk-D domains whereas neuferricin further gained a SH3 and a PDK1 binding domain (Table 2).

\section{Syntenic analysis of mPR and MAPR genes among five chordates}

Five genes flanking the mPR and MAPR genes were presented and compared among human, mouse, zebrafish, lampreys and Florida lancelet (Additional file 11). In general, gene arrangement was conserved among human, mouse and zebrafish genomes. Lampreys only contained partial gene synteny near $\mathrm{mPR} \varepsilon$ and neudesin, similar to human, mouse and zebrafish. Syntenic genes were not found near mPR and MAPR genes (Fig. 5 and Additional file 11).

The gene arrangement on both sides of PAQR8 $(\mathrm{mPR} \beta)$ was identical, with nine contiguous genes in human and mouse. Zebrafish genome contained three syntenic genes (Il17a/f3-mcm3) $5^{\prime}$ to paqr8 similar to mouse genome, whereas lampreys and four other species did not exhibit similar gene synteny. In lancelet, we identified nine mPR $\beta$ genes. Most of them were in tandem arrangement in two scaffolds, demonstrating gene expansion via tandem duplication (Additional file 11). Compared to the gene arrangement on both sides of PAQR5 (mPR $\gamma$ ) in human, NOX5 gene was translocated to different chromosome in mouse genome. Zebrafish genome contained paqr5a and paqr5b, generated by genome duplication, evidenced from well-conserved synteny $3^{\prime}$ to paqr5a and on both sides of paqr5b, similar to mouse genome. No gene synteny was shared among lampreys and other four species. Compared to gene arrangement on both sides of PAQR6 (mPR $\delta$ ) in human genome, three tandem copies of Bglap occurred $5^{\prime}$ to Paqr6, and the VHLL gene was translocated to a different chromosome in the mouse genome. The zebrafish genome preserved one gene (smg5) 3' to paqr6, similar to the mouse genome. However, no gene synteny was shared among lampreys and other three species (no $\mathrm{mPR} \delta$ in lancelet). The gene arrangement on both sides of PAQR9 (mPRe) was identical between human and mouse. Compared to the mouse genome, the zebrafish genome contained one gene (pcolceb) while lamprey preserved two genes (trpc1pcolce2) 5 ' to paqr9 (Fig. 5a).

Compared to gene arrangement flanking PGRMC1 in human genome, KIAA1210 was translocated to different chromosome and Akap17b was inserted at the $3^{\prime}$ end in the mouse genome. Zebrafish, lamprey and lancelet did not share any synteny with human and mouse (Additional file 11). The gene arrangement on both ends of PGRMC2 were identical in human and mouse. Zebrafish shared a syntenic block (larp1b, pgrmc 2 and jade1) with an insertion of asmt 2 compared to mouse. The gene arrangement on both sides of NENF (neudesin) was completely identical in human and mouse. Both zebrafish and lamprey (but not lancelet) shared synteny (tmem206 and nenf) with human and mouse (Fig. 5b). Compared to the gene arrangement on both ends of CYB5D2 (neuferricin) in human, RYKP1 gene was translocated to the 3' end in mouse. Zebrafish and mouse shared a wellconserved syntenic block containing nine contiguous genes including an inversion between $\mathrm{p} 2 \mathrm{rx} 1$ and camkk1 (Additional file 11).

\section{Discussion}

The evolution of $n P R, m P R$ and MAPR genes

Phylogenetic analyses of metazoan PR homologous sequences support the notion that the membranebound PRs, mPRs and PGRMC, likely evolved before $\mathrm{nPR}$ since they appeared at the basal animal lineage, and probably originated from an ancestral Hly-III- 


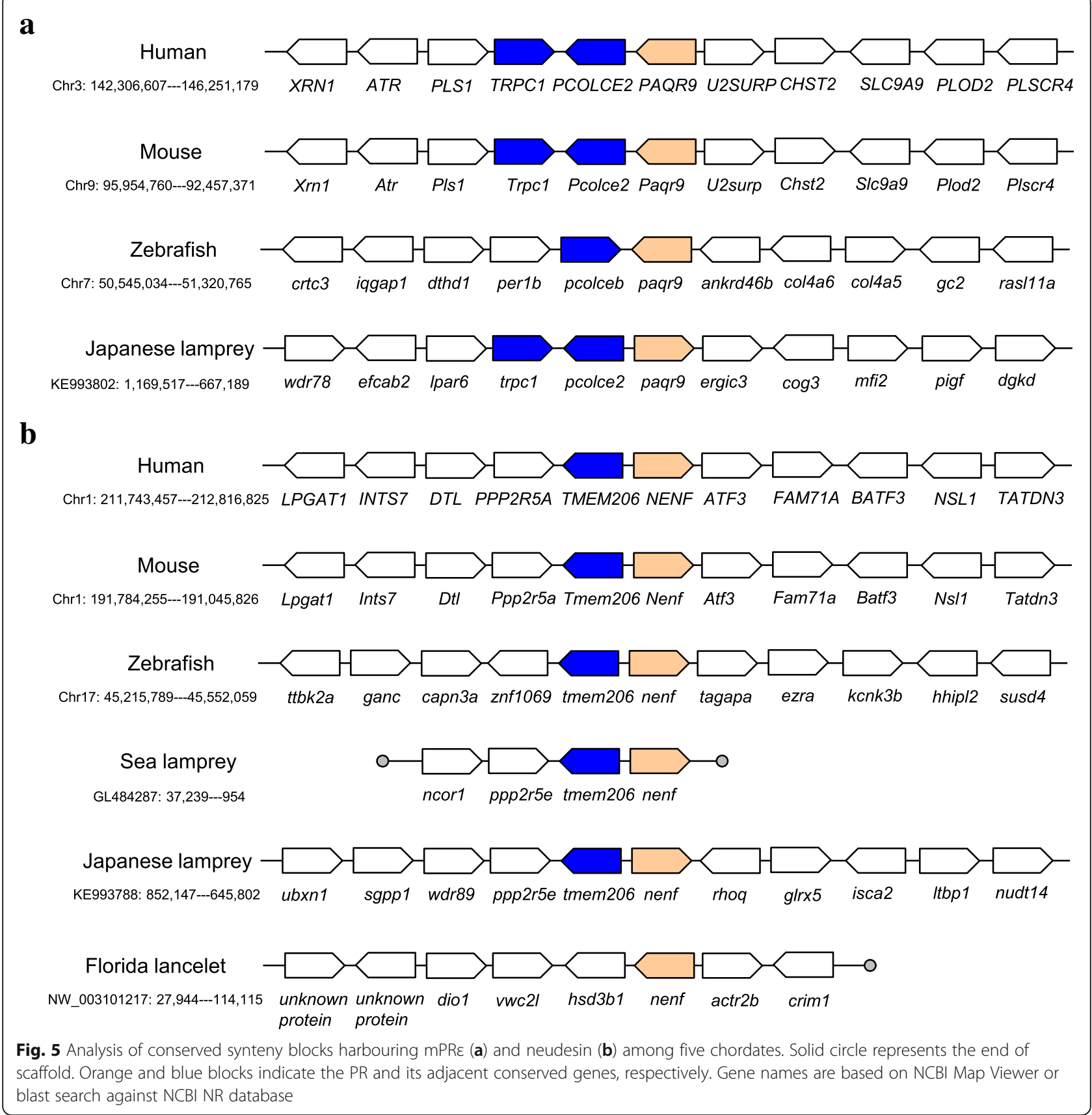

containing protein and cyt-b5-containing protein, respectively [13]. During metazoan evolution, new $\mathrm{mPR}$ and MAPR sequences probably derived from gene duplications. The genes for $\mathrm{nPR}$ appeared later in the vertebrate lineage, tracing back to an early common ancestor with ER [47], and a last common ancestor with corticoid receptor [29]. The appearance of nPR in vertebrates endowed a new mode of $\mathrm{P}_{4}$ function by directly acting on the genome to regulate gene transcriptions, in addition to the cellular responses through the membrane receptors.

The conservation and expansion of mPR gene family during metazoan evolution

The $\mathrm{mPR}$ gene family is conserved in all metazoan phyla examined, and its ancestral sequences can be traced back to Eubacteria [48]. The mPR gene family expanded from one $(\mathrm{mPR} \gamma)$ to five members $(\mathrm{mPR} \alpha, \beta, \gamma, \delta$, and $\varepsilon)$ 


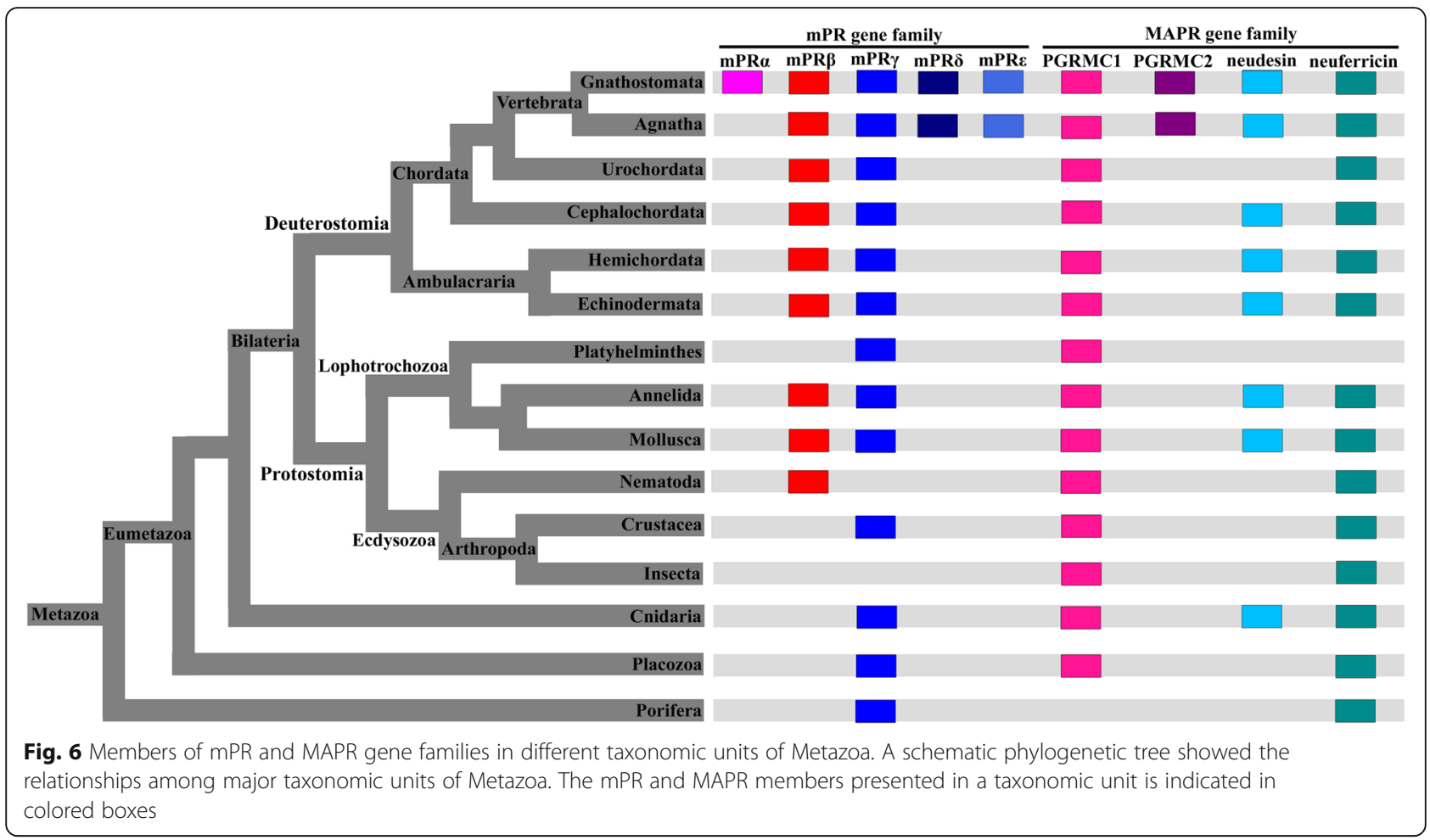

during metazoan evolution (Fig. 6). Our phylogenetic analyses revealed that the $\mathrm{mPR} \gamma$ gene first appeared in non-bilaterians and the $\mathrm{mPR} \beta$ gene arose from the early duplication of the mPR $\gamma$ gene in bilaterians. $\mathrm{mPR} \delta$ and $\varepsilon$ genes also arose from duplications of the mPRy gene, but these events occurred much later in vertebrate lineages from lamprey to human. On the contrary, the $\mathrm{mPR} \alpha$ gene first appeared in cartilaginous fishes, probably from the duplication of the $\operatorname{mPR} \beta$ gene after the agnathan-gnathostome divergence (Fig. 6). In addition, $\operatorname{mPR} \beta$ and $\gamma$ genes underwent species-specific duplications and expanded into multiple copies $(>2)$ in several species such as Florida lancelet, owl limpet, pacific oyster, sea urchin, placozoan and sea anemone (Additional file 2). In Florida lancelet and sea anemone, the copy number for $\operatorname{mPR} \beta$ and $\mathrm{mPR} \gamma$ genes reached up to nine and seven, respectively (Table 3 ). The multiple copies in speciesspecific duplications were often in tandem arrangement via tandem duplication as demonstrated in lancelet $\mathrm{mPR} \beta$ (Additional file 11). Only $\mathrm{mPR} \alpha$ showed lineage-specific duplication in teleosts, probably due to teleost-specific third-round whole genome duplication (3R-WGD). Unlike $\operatorname{mPR} \alpha, \beta$ or $\gamma$, neither $\operatorname{mPR} \delta$ nor $\varepsilon$ showed lineage- or species-specific duplication and contained only one copy (Table 3).

Surprisingly, none of the mPR members were identified in all six insect genomes examined (Fig. 6 and Additional file 2). Further investigation of additional insect genomes is required to conclude whether the $\mathrm{mPR}$ gene family is indeed lost in the insect lineage.

\section{Conservation of the MAPR gene family during metazoan evolution}

MAPRs are a group of rather small, partially homologous proteins, which share a similar non-covalent hemebinding domain related to cytochrome b5 [49]. The heme-binding cyt-b5 domain may serve as a template for more recently-evolved novel ligand binding pockets, such as a steroid-binding site in the MAPR proteins [12]. Most proteins with a cyt-b5 domain are linked to cell membranes, either directly or by forming part of the membrane-associated complexes [12]. The proximity of cell membranes to a heme-binding template pocket allowed the binding specificity for membrane-soluble molecules such as steroids. Thus, MAPRs may represent an adaptation to use steroids as triggers for fast-acting mechanisms [12]. Progesterone-binding activity has rarely been demonstrated directly in purified MAPR proteins [24]. Recent studies showed that progesterone binds to human PGRMC1 [24], similar to the first PGRMC1 isolated from porcine liver cell membranes with high $\mathrm{P}_{4}$ binding affinity [23]. Another study also demonstrated that human PGRMC1 acted as an adaptor protein for the mPR protein complex [25]. Therefore, PGRMC1 is likely involved in progesterone signaling pathway as either a receptor or an adaptor protein, or both. 
The MAPR genes likely evolved in plants, fungi and metazoans and PGRMC1-like genes apparently evolved in early eukaryotes $[3,12]$. Ancestral metazoans may contain three MAPR genes, corresponding to ancestral PGRMC, neudesin, and neuferricin [3]. A previous study showed that PGRMC1 and PGRMC2 diverged in early chordates, or possibly in insect lineages [3]. Our phylogenetic analyses demonstrated that the MAPR gene family initially contained three members (PGRMC1, neudesin, and neuferricin), supporting the notion that PGRMC1 and PGRMC2 diverged in vertebrate lineage since two PGRMC members first appeared in lamprey genomes (The PGRMC genes of fruit fly identified in [3] were in fact three copies of PGRMC1, not PGRMC2). The choanoflagellate, the closest unicellular living relative of the metazoans, contained only PGRMC1 and neuferricin (Table 3). In addition, MAPR members showed some species-specific duplication, resulting in three copies of PGRMC1 in polychaete worm and fruit fly, and two copies of neuferricin in sea anemone, sea urchin and lancelet, which may derive from tandem duplication (Additional file 11). Vertebrate species harbored all four MAPR members without obvious expansions from lamprey to human, even in teleosts with 3R-WGD.

\section{Progesterone signaling: from membrane to nucleus}

It appears that the mPR or MAPR genes evolved earlier than the nPR genes [29-35]. It is believed that nPR genes descended from a single promiscuous ancestral steroid receptor gene in protostomes, which branched off from the rest of the nuclear receptor superfamily early in animal evolution [39]. The specificity in more recent receptor proteins has been tuned by natural selection [50]. The ability of ancient receptors to interact with many ligands allowed species with small protein repertoires to carry out broad biological activities and promoted future evolution of new functions. Specialization in more recent receptor proteins provides greater efficiency, finer regulation, or prevention of deleterious interactions [50]. The ligand binding ability likely evolved through a process of molecular exploitation; i.e., the evolution of new ligand/receptor interactions when an older receptor is co-opted to bind a newly-evolved ligand [39, 50]. Indeed, based on shared steroid metabolic pathways among different taxa, Markov et al. deduced that the estrogen-binding ability evolved before the ability to bind other side-chain cleaved steroids and the ancestral ligand to the first steroidbinding receptor was not an 18-carbon estrogen but likely a molecule with a side chain in addition to the aromatic A-ring specific to vertebrate estrogens [51].

$\mathrm{P}_{4}$-sensitivity of these receptors in early metazoa probably acted as a sensor for exogenous progestins produced by other taxa in the environment [39, 52]. The cyp11a gene, encoding the P450 enzyme that converts cholesterol to pregnenolone, exists in deuterostomes
[53]. The genes encoding $3 \beta-H S D$ enzymes that convert pregnenolone to $\mathrm{P}_{4}$ are present in the fungus Aspergillus fumigatus [54]. $\mathrm{P}_{4}$ and its synthetic enzymes have been unambiguously detected in cephalochordates [55], and $\mathrm{P}_{4}$ has been identified in mollusks by gas or liquid chromatography/mass spectrometry [56, 57]. High levels of exogenous $\mathrm{P}_{4}$ inhibit growth in fungal yeast cells via membrane $\mathrm{P}_{4}$ receptors [32]. Experimental evidence also demonstrates that functional progesterone membraneassociated receptor exists in invertebrate rotifer Brachionus manjavacas [33]. Therefore, the $\mathrm{P}_{4}$ binding ability of mPR, MAPR and nPRs likely evolved through molecular exploitation $[39,50]$, and the function of these receptors in early metazoa is probably not for reproduction, but rather for chemoreception [39, 52, 58, 59].

Most membrane receptor families evolved at the advent of multicellularity and coincided with the need for coordinated cellular behaviors [60]. The mPRs containing 7TM domains were thought to be unique GPCRs $[19,61]$. GPCRs are among the first group of receptors to emerge in unicellular organisms [62, 63]. Their ligands, including light-sensitive compounds, odorants, hormones, and neurotransmitters, induce a conformational change upon binding with the receptors, which activates two principal signal transduction pathways, the cAMP and the phosphatidylinositol signaling pathways, resulting in signal amplification from the exterior to the interior of cells $[64,65]$.

\section{Conclusions}

In conclusion, non-classical mPR and MAPR genes first evolved in non-bilaterians and classical nPR genes evolved later in basal vertebrates. Sequence repertoires for mPRs and MAPRs in vertebrates likely originated from an ancestral metazoan sequence and expanded via several gene duplication events.

\section{Methods \\ Identification of $\mathrm{nPR}, \mathrm{MPR}$ and MAPR sequences in lampreys}

The genomic resources used for these analyses include the nucleotide and protein sequences from the sea lamprey and Japanese lamprey genomes, and a sea lamprey transcriptomic sequences. The sea lamprey transcriptomic sequences were obtained through assembling 86 Illumina RNA-Seq samples from various tissues across different developmental stages. The RNA-Seq data were generated during the sequencing project of sea lamprey genome. Sixteen samples have been published in [43] and the remaining data has not been published. The Lamprey tissues for Illumina transcriptomic assembly include 1) four development stage embryos, 2) larval gill, kidney, liver and intestine, 3) seven metamorphosis stage liver, intestine and kidney, 4) juvenile and adult intestine, 
liver and kidney, 5) other adult tissues (see more information in $[43,66])$. All available $\mathrm{nPR}, \mathrm{mPR}$ and MAPR sequences of human (Homo sapiens), mouse (Mus musculus) and zebrafish (Danio rerio) were retrieved from Ensembl (http://www.ensembl.org/index. html) and used as queries to search against the genomic resources by stand-alone BLASTP or TBLASTN. The coding regions from retrieved RNA-Seq transcripts were predicted using GETORF of the EMBOSS online tool (EMBOSS GUI v1.14). The resulting protein sequences were validated by BLASTP against NCBI non-redundant protein sequence database (nr) to ascertain that these identified proteins are actual progesterone receptors and not some members of Class II PAQR family. These sea lamprey and Japanese lamprey PR sequences have been deposited in GenBank and listed in Additional file 1. The conserved protein domains were predicted with SMART (simple modular architecture research tool) [67]. The transcripts of the identified genes were mapped to lamprey genomic sequences for gene structure analyses and then drawn with FancyGene [68].

\section{Identification of $\mathrm{nPR}, \mathrm{mPR}$ and MAPR homologous sequences in selective metazoans}

Deduced amino acid sequences from different metazoan taxonomies were downloaded from the Ensembl genome browser (release75), including Porifera (Amphimedon queenslandica), Placozoa (Trichoplax adhaerens), Cnidaria (Nematostella vectensis), Insecta (Acyrthosiphon pisum, Anopheles gambiae, Apis mellifera, Bombyx mori, Drosophila melanogaster, and Tribolium castaneum), Crustacea (Daphnia pulex), Nematoda (Caenorhabditis elegans), Mollusca (Crassostrea gigas and Lottia gigantea), Annelida (Capitella teleta and Helobdella robusta), Platyhelminthes (Schistosoma mansoni), Echinodermata (Strongylocentrotus purpuratus), Hemichordata (Saccoglossus kowalevskii and Ptychodera flava), Urochordata (Ciona intestinalis and C. savignyi), Chondrichthyes (elephant shark, Callorhinchus milii), Osteichthyes [(spotted gar, Lepisosteus oculatus), takifugu (Takifugu rubripes), medaka (Oryzias latipes), and coelacanth (Latimeria chalumnae)], Amphibia (Xenopus tropicalis), Reptilia (Anolis carolinensis) and Aves (Gallus gallus). Amino acid sequences of Cephalochordata (Branchiostoma floridae) were downloaded from NCBI RefSeq (http://www. ncbi.nlm.nih.gov/refseq/). These amino acid sequences were subjected to BLASTP search against the nPR, mPR and MAPR proteins from human, mouse and zebrafish genomes. The BLAST hit proteins were then confirmed by BLASTP against NCBI nr database to ascertain that these identified proteins are actual progesterone receptors and not some members of Class II PAQR family.

\section{Phylogenetic analyses of $\mathrm{nPR}, \mathrm{mPR}$ and MAPR} homologous sequences

Representatives of $\mathrm{nPR}, \mathrm{mPR}$ and MAPR protein sequences identified from aforementioned metazoan species were used for phylogenetic analyses (Additional file 2). In addition, ER and estrogen-related receptor (ERR) gene sequences were chosen as the out groups to infer the origin and evolution of nPR in metazoans (Additional file 2), including sequences from human, mouse, zebrafish, lampreys, Florida lancelet (B. floridae), fruit fly, red flour beetle ( $T$. castaneum) and placozoa ( $T$. adhaerens). Protein sequences in each gene family were aligned by ClustalW2 [69].

Phylogenetic analyses were performed using both neighbor joining (NJ) and maximum likelihood (ML) approaches with 100 bootstrap replicates using MEGA6 software package [70]. The NJ and ML trees for selected PR proteins were built with a JTT substitution model. In the NJ trees, gaps/missing data were treated by paired deletion, whereas in the ML trees, all sites were used.

\section{Syntenic comparisons of MPR and MAPR genes among five chordates}

Protein-coding genes adjacent to $\mathrm{mPR}$ and MAPR genes in human, mouse, zebrafish and Florida lancelet genomes were identified from NCBI Map Viewer. The gene arrangements in lampreys were investigated with lamprey genome annotation files. The gene names of lamprey and Florida lancelet were further confirmed by BLASTP against NCBI human, mouse, zebrafish and nr databases. Five genes adjacent to MPR and MAPR genes in both directions ( $5^{\prime}$ and $\left.3^{\prime}\right)$ were presented and compared among human, mouse, zebrafish, lampreys and Florida lancelet.

\section{Protein motif analyses}

Protein motifs were predicted using the Scansite cell signaling interactions prediction "MotifScan" module (https:// scansite4.mit.edu/4.0/\#scanProtein) under medium and high stringency settings.

\section{Additional files}

Additional file 1: Sequences of $n P R, m P R$ and MAPR genes identified in Japanese lamprey. (TXT $11 \mathrm{~kb}$ )

Additional file 2: Species selected for phylogenetic analyses of $n P R$, mPR and MAPR genes. (XLSX $20 \mathrm{~kb}$ )

Additional file 3: Gene structure of $n P R, m P R$ and MAPR genes in human, mouse and zebrafish. (PDF $368 \mathrm{~kb}$ )

Additional file 4: Predicted motif sequences for lamprey PRs using the Scansite cell signaling interactions prediction "MotifScan" module. (XLSX 15 kb) Additional file 5: A phylogenetic tree constructed by the ML method demonstrates the evolutionary relationship among $n P R$, ER and ERR in metazoans. (PDF $12 \mathrm{~kb}$ )

Additional file 6: Gene location of $\mathrm{MPR}$ and MAPR genes in sea lamprey and Japanese lamprey. (XLSX $30 \mathrm{~kb}$ ) 
Additional file 7: Gene structure of four transcript isoforms of sea lamprey mPRß. (JPG $1194 \mathrm{~kb}$ )

Additional file 8: Gene structure of four transcript isoforms of sea lamprey mPRS. (JPG $1112 \mathrm{~kb}$ )

Additional file 9: A phylogenetic tree constructed by the ML method demonstrates the evolutionary relationship among five members of mPR gene family in metazoans. (PDF $16 \mathrm{~kb}$ )

Additional file 10: Phylogenetic trees constructed by the ML method demonstrate the evolutionary relationship of PGRMC, neudesin and neuferricin in metazoans. (JPG $4300 \mathrm{~kb}$ )

Additional file 11: Syntenic analysis of mPRs and MAPRs genomic sequences among human, mouse, zebrafish and lampreys. (PPTX 169 kb)

\section{Abbreviations \\ 3R-WGD: Third-round whole genome duplication; 7TM: Seven trans- membrane; CDS: Coding DNA sequence; cyt-b5: Cytochrome b5; DBD: DNA- binding domain; ER: Estrogen receptor; ERR: Estrogen-related receptor; GPCR: G-protein coupled receptor; LBD: Ligand-binding domain; MAPR: Membrane-associated progesterone receptor; mPR: Membrane progestin receptor; $\mathrm{nPR}$ : Nuclear progesterone receptor; $\mathrm{P}_{4}$ : Progesterone; PAQR: Progestin and adipoQ receptor; PGRMC1: Progesterone receptor membrane component 1; PR: Progesterone receptor; UTR: Untranslated region}

\section{Acknowledgements}

We thank Dr. Chenhong Li (Shanghai Ocean University) for his assistance in constructing the phylogenetic trees.

\section{Authors' contributions}

JR and WL conceived the study; JR and YWCD performed data analyses and drafted the manuscript; $L$ and $W L$ edited and revised the manuscript. All authors read and approved the final manuscript.

\section{Funding}

This work was mainly supported by the International S\&T Cooperation Programs from Shanghai Committee of Science and Technology (15410723300) and the Ph.D. Startup Fund of Shanghai Ocean University (A2-0203-00-100318). We are also grateful for the support of the SHOU\&MSU Joint Research Center grant. YWCD and WL also received support from the Great Lakes Fishery Commission and the Seed Fund from the Office of the Vice President for Research and Graduate Studies and AgBio Research Center at Michigan State University. The funding body played no role in the design of the study and collection, analysis, and interpretation of data and in writing the manuscript.

\section{Availability of data and materials}

All data analyzed in this study are included within the article and its additional files. The PR gene sequences of sea lamprey have been deposited in GenBank database (accession numbers: KT970648-KT970662) whereas the Japanese lamprey PR gene sequences are included in Additional file 1.

\section{Ethics approval and consent to participate}

Not Applicable.

\section{Consent for publication}

Not Applicable.

\section{Competing interests}

The authors declare that they have no competing interests.

\section{Author details}

${ }^{1}$ International Research Center for Marine Biosciences, Ministry of Science and Technology, Shanghai Ocean University, Shanghai 201306, China. ${ }^{2}$ Department of Fisheries and Wildlife, Michigan State University, East Lansing, MI 48824, USA. ${ }^{3}$ Key Laboratory of Exploration and Utilization of Aquatic Genetic Resources, Ministry of Education, Shanghai Ocean University, Shanghai 201306, China. ${ }^{4}$ Key Laboratory of Freshwater Aquatic Genetic Resources, Ministry of Agriculture, Shanghai Ocean University, Shanghai 201306, China.
Received: 10 July 2018 Accepted: 18 June 2019

Published online: 01 July 2019

\section{References}

1. Madauss KP, Stewart EL, Williams SP. The evolution of progesterone receptor ligands. Med Res Rev. 2007;27(3):374-400.

2. Rohe HJ, Ahmed IS, Twist KE, Craven RJ. PGRMC1 (progesterone receptor membrane component 1): a targetable protein with multiple functions in steroid signaling, P450 activation and drug binding. Pharmacol Ther. 2009; 121(1):14-9.

3. Cahill MA. Progesterone receptor membrane component 1: an integrative review. J Steroid Biochem Mol Biol. 2007;105(1-5):16-36.

4. ter Horst JP, de Kloet ER, Schachinger H, Oitzl MS. Relevance of stress and female sex hormones for emotion and cognition. Cell Mol Neurobiol. 2012; 32(5):725-35.

5. Watson S, Gallagher P, Porter RJ, Smith MS, Herron L, Bulmer S, Young AH, Ferrier IN. A randomized trial to examine the effect of mifepristone on neuropsychological performance and mood in patients with bipolar depression. Biol Psychiatry. 2012;72(11):943-9.

6. Bali N, Arimoto JM, Iwata N, Lin SW, Zhao L, Brinton RD, Morgan TE, Finch $C E$. Differential responses of progesterone receptor membrane component1 (Pgrmc1) and the classical progesterone receptor (Pgr) to 17ß-estradiol and progesterone in hippocampal subregions that support synaptic remodeling and neurogenesis. Endocrinology. 2012;153(2):759-69.

7. Charalampopoulos I, Remboutsika E, Margioris AN, Gravanis A. Neurosteroids as modulators of neurogenesis and neuronal survival. Trends Endocrinol Metab. 2008;19(8):300-7.

8. Giatti S, Boraso M, Melcangi RC, Viviani B. Neuroactive steroids, their metabolites, and neuroinflammation. J Mol Endocrinol. 2012;49(3):R125-34.

9. Singh M. Progesterone-induced neuroprotection. Endocrine. 2006;29(2):271-4.

10. Baudry M, Bi X, Aguirre C. Progesterone-estrogen interactions in synaptic plasticity and neuroprotection. Neuroscience. 2013;239(0):280-94.

11. Sanchez AM, Flamini MI, Genazzani AR, Simoncini T. Effects of progesterone and medroxyprogesterone on actin remodeling and neuronal spine formation. Mol Endocrinol. 2013;27(4):693-702.

12. Mifsud W, Bateman A. Membrane-bound progesterone receptors contain a cytochrome b5-like ligand-binding domain. Genome Biol. 2002;3(12): RESEARCH0068

13. Smith JL, Kupchak BR, Garitaonandia I, Hoang LK, Maina AS, Regalla LM Lyons TJ. Heterologous expression of human mPRalpha, mPRbeta and mPRgamma in yeast confirms their ability to function as membrane progesterone receptors. Steroids. 2008;73(11):1160-73.

14. Kimura I, Nakayama Y, Konishi M, Terasawa K, Ohta M, Itoh N, Fujimoto M. Functions of MAPR (membrane-associated progesterone receptor) family members as heme/steroid-binding proteins. Curr Protein Pept Sci. 2012; 13(7):687-96.

15. Zhu Y, Rice CD, Pang Y, Pace M, Thomas P. Cloning, expression, and characterization of a membrane progestin receptor and evidence it is an intermediary in meiotic maturation of fish oocytes. Proc Natl Acad Sci U S A. 2003;100(5):2231-6.

16. Zhu Y, Bond J, Thomas P. Identification, classification, and partial characterization of genes in humans and other vertebrates homologous to a fish membrane progestin receptor. Proc Natl Acad Sci U S A. 2003;100(5): 2237-42.

17. Zhu Y, Hanna RN, Schaaf MJ, Spaink HP, Thomas P. Candidates for membrane progestin receptors--past approaches and future challenges. Comp Biochem Physiol C Toxicol Pharmacol. 2008;148(4):381-9.

18. Thomas P. Characteristics of membrane progestin receptor alpha (mPRalpha) and progesterone membrane receptor component 1 (PGMRC1) and their roles in mediating rapid progestin actions. Front Neuroendocrinol. 2008;29(2):292-312

19. Pang $Y$, Dong J, Thomas $P$. Characterization, neurosteroid binding and brain distribution of human membrane progesterone receptors delta and \{epsilon\} (mPRdelta and mPR \{epsilon\}) and mPRdelta involvement in neurosteroid inhibition of apoptosis. Endocrinology. 2013;154(1):283-95.

20. Gerdes D, Wehling M, Leube B, Falkenstein E. Cloning and tissue expression of two putative steroid membrane receptors. Biol Chem. 1998;379(7):907-11.

21. Kimura I, Yoshioka M, Konishi M, Miyake A, Itoh N. Neudesin, a novel secreted protein with a unique primary structure and neurotrophic activity. J Neurosci Res. 2005;79(3):287-94. 
22. Kimura I, Nakayama Y, Konishi M, Kobayashi T, Mori M, Ito M, Hirasawa A, Tsujimoto G, Ohta M, Itoh N, et al. Neuferricin, a novel extracellular hemebinding protein, promotes neurogenesis. J Neurochem. 2010;112(5):1156-67.

23. Meyer C, Schmid R, Scriba PC, Wehling M. Purification and partial sequencing of high-affinity progesterone-binding site(s) from porcine liver membranes. Eur J Biochem. 1996;239(3):726-31.

24. Kaluka D, Batabyal D, Chiang BY, Poulos TL, Yeh SR. Spectroscopic and mutagenesis studies of human PGRMC1. Biochemistry. 2015;54(8):1638-47.

25. Thomas $P$, Pang $Y$, Dong J. Enhancement of cell surface expression and receptor functions of membrane progestin receptor alpha (mPRalpha) by progesterone receptor membrane component 1 (PGRMC1): evidence for a role of PGRMC1 as an adaptor protein for steroid receptors. Endocrinology. 2014;155(3):1107-19.

26. Wendler A, Wehling M. PGRMC2, a yet uncharacterized protein with potential as tumor suppressor, migration inhibitor, and regulator of cytochrome P450 enzyme activity. Steroids. 2013;78(6):555-8.

27. Petersen SL, Intlekofer KA, Moura-Conlon PJ, Brewer DN, Del Pino Sans J, Lopez JA. Novel progesterone receptors: neural localization and possible functions. Front Neurosci. 2013;7:164.

28. Petersen SL, Intlekofer KA, Moura-Conlon PJ, Brewer DN, Del Pino Sans J, Lopez JA. Nonclassical progesterone signalling molecules in the nervous system. J Neuroendocrinol. 2013;25(11):991-1001.

29. Thornton JW. Evolution of vertebrate steroid receptors from an ancestral estrogen receptor by ligand exploitation and serial genome expansions. Proc Natl Acad Sci U S A. 2001;98(10):5671-6.

30. Bridgham JT, Brown JE, Rodriguez-Mari A, Catchen JM, Thornton JW Evolution of a new function by degenerative mutation in cephalochordate steroid receptors. PLoS Genet. 2008;4(9):e1000191.

31. Katsu Y, Kubokawa K, Urushitani H, Iguchi T. Estrogen-dependent transactivation of amphioxus steroid hormone receptor via both estrogen and androgen response elements. Endocrinology. 2010;151(2):639-48.

32. Gonzalez-Velazquez W, Gonzalez-Mendez R, Rodriquez-del Valle N. Characterization and ligand identification of a membrane progesterone receptor in fungi: existence of a novel PAQR in Sporothrix schenckii. BMC Microbiol. 2012;12:194.

33. Stout EP, La Clair JJ, Snell TW, Shearer TL, Kubanek J. Conservation of progesterone hormone function in invertebrate reproduction. Proc Natl Acad Sci U S A. 2010;107(26):11859-64.

34. Villa NY, Moussatche P, Chamberlin SG, Kumar A, Lyons TJ. Phylogenetic and preliminary phenotypic analysis of yeast PAQR receptors: potential antifungal targets. J Mol Evol. 2011;73(3-4):134-52.

35. Smith HA, Welch DBM, Snell TW. Molecular evolution of the membrane associated progesterone receptor in the Brachionus plicatilis (Rotifera, Monogononta) species complex. Hydrobiologia. 2011;662(1):99-106.

36. Bentley GE, Wilsterman K, Ernst DK, Lynn SE, Dickens MJ, Calisi RM, Kriegsfeld LJ, Kaufer D, Geraghty AC, viviD D, et al. Neural versus gonadal $\mathrm{GnlH}$ : are they independent systems? A mini-review. Integr Comp Biol. 2017; 57(6):1194-203.

37. Scott AP. Is there any value in measuring vertebrate steroids in invertebrates? Gen Comp Endocrinol. 2018;265:77-82.

38. Lafont R, Mathieu M. Steroids in aquatic invertebrates. Ecotoxicology. 2007 16(1):109-30.

39. Eick GN, Thornton JW. Evolution of steroid receptors from an estrogensensitive ancestral receptor. Mol Cell Endocrinol. 2011;334(1-2):31-8.

40. Kumar S, Hedges SB. A molecular timescale for vertebrate evolution. Nature. 1998;392(6679):917-20.

41. Shu DG, Luo HL, Conway Morris S, Zhang XL, Hu SX, Chen L, Han J, Zhu M, Li Y, Chen LZ. Lower Cambrian vertebrates from South China. Nature. 1999; 402(6757):42-6.

42. Bryan MB, Chung-Davidson YW, Ren J, Bowman S, Scott AP, Huertas M, Connolly MP, Li W. Evidence that progestins play an important role in spermiation and pheromone production in male sea lamprey (Petromyzon marinus). Gen Comp Endocrinol. 2015;212:17-27.

43. Smith JJ, Kuraku S, Holt C, Sauka-Spengler T, Jiang N, Campbell MS, Yandell MD, Manousaki T, Meyer A, Bloom OE, et al. Sequencing of the sea lamprey (Petromyzon marinus) genome provides insights into vertebrate evolution. Nat Genet. 2013:45(4):415-21 421e411-412.

44. Mehta TK, Ravi V, Yamasaki S, Lee AP, Lian MM, Tay B-H, Tohari S, Yanai S, Tay A, Brenner S, et al. Evidence for at least six Hox clusters in the Japanese lamprey (Lethenteron japonicum). Proc Natl Acad Sci. 2013; 110(40):16044-9.
45. Giangrande PH, Pollio G, McDonnell DP. Mapping and characterization of the functional domains responsible for the differential activity of the a and B isoforms of the human progesterone receptor. J Biol Chem. 1997;272(52): 32889-900.

46. Bain DL, Heneghan AF, Connaghan-Jones KD, Miura MT. Nuclear receptor structure: implications for function. Annu Rev Physiol. 2007;69: 201-20.

47. Sáez PJ, Lange S, Pérez-Acle T, Owen Gl. Nuclear Receptor Genes: Evolution. In: eLS. Medford: Wiley; 2010. http://www.els.net/WileyCDA/.

48. Thomas P, Pang Y, Dong J, Groenen P, Kelder J, de Vlieg J, Zhu Y, Tubbs C. Steroid and $G$ protein binding characteristics of the seatrout and human progestin membrane receptor alpha subtypes and their evolutionary origins. Endocrinology. 2007;148(2):705-18.

49. Ryu CS, Klein K, Zanger UM. Membrane associated progesterone receptors: promiscuous proteins with pleiotropic functions - focus on interactions with cytochromes P450. Front Pharmacol. 2017:8:159.

50. Eick GN, Colucci JK, Harms MJ, Ortlund EA, Thornton JW. Evolution of minimal specificity and promiscuity in steroid hormone receptors. PLoS Genet. 2012;8(11):e1003072.

51. Markov GV, Gutierrez-Mazariegos J, Pitrat D, Billas IML, Benneton F, Moras D, Hasserodt J, Lecointre G, Laudet V. Origin of an ancient hormone/receptor couple revealed by resurrection of an ancestral estrogen. Sci Adv. 2017;3: e1601778.

52. Markov GV, Tavares R, Dauphin-Villemant C, Demeneix BA, Baker ME, Laudet $\checkmark$. Independent elaboration of steroid hormone signaling pathways in metazoans. Proc Natl Acad Sci U S A. 2009;106(29):11913-8.

53. Goldstone JV, Sundaramoorthy M, Zhao B, Waterman MR, Stegeman JJ, Lamb DC. Genetic and structural analyses of cytochrome P450 hydroxylases in sex hormone biosynthesis: sequential origin and subsequent coevolution. Mol Phylogenet Evol. 2016;94(Pt B):676-87.

54. Nierman WC, Pain A, Anderson MJ, Wortman JR, Kim HS, Arroyo J, Berriman M, Abe K, Archer DB, Bermejo C, et al. Genomic sequence of the pathogenic and allergenic filamentous fungus Aspergillus fumigatus. Nature. 2005:438(7071):1151-6.

55. Mizuta T, Kubokawa K. Presence of sex steroids and cytochrome P450 genes in amphioxus. Endocrinology. 2007;148(8):3554-65.

56. Reis-Henriques MA, Coimbra J. Variations in the levels of progesterone in Mytilus edulis during the annual reproductive cycle. Comp Biochem Physiol A. 1990;95:343-8.

57. Stefano GB, Cadet P, Mantione K, Cho JJ, Jones D, Zhu W. Estrogen signaling at the cell surface coupled to nitric oxide release in Mytilus edulis nervous system. Endocrinology. 2003;144(4):1234-40.

58. Scott AP. Do mollusks use vertebrate sex steroids as reproductive hormones? II. Critical review of the evidence that steroids have biological effects. Steroids. 2013;78(2):268-81.

59. Scott AP. Do mollusks use vertebrate sex steroids as reproductive hormones? Part I: critical appraisal of the evidence for the presence, biosynthesis and uptake of steroids. Steroids. 2012;77(13):1450-68.

60. Kaiser D. Building a multicellular organism. Annu Rev Genet. 2001;35(1): 103-23.

61. Thomas $P$, Pang Y. Membrane progesterone receptors: evidence for neuroprotective, neurosteroid signaling and neuroendocrine functions in neuronal cells. Neuroendocrinology. 2012;96(2):162-71.

62. Krishnan A, Almen MS, Fredriksson R, Schioth HB. The origin of GPCRs: identification of mammalian like rhodopsin, adhesion, glutamate and frizzled GPCRs in fungi. PLoS One. 2012;7(1):e29817.

63. Nordstrom KJ, Sallman Almen M, Edstam MM, Fredriksson R, Schioth HB. Independent HHsearch, Needleman--Wunsch-based, and motif analyses reveal the overall hierarchy for most of the $\mathrm{G}$ protein-coupled receptor families. Mol Biol Evol. 2011;28(9):2471-80.

64. Ben-Shlomo I, Yu Hsu S, Rauch R, Kowalski HW, Hsueh AJ. Signaling receptome: a genomic and evolutionary perspective of plasma membrane receptors involved in signal transduction. Sci STKE. 2003;2003(187):RE9.

65. King N, Hittinger CT, Carroll SB. Evolution of key cell signaling and adhesion protein families predates animal origins. Science. 2003; 301(5631):361-3.

66. Ren J, Chung-Davidson YW, Yeh CY, Scott C, Brown T, Li W. Genome-wide analysis of the ATP-binding cassette $(A B C)$ transporter gene family in sea lamprey and Japanese lamprey. BMC Genomics. 2015;16:436.

67. Letunic I, Doerks T, Bork P. SMART 7: recent updates to the protein domain annotation resource. Nucleic Acids Res. 2012;40(Database issue):D302-5. 
68. Rambaldi D, Ciccarelli FD. FancyGene: dynamic visualization of gene structures and protein domain architectures on genomic loci. Bioinformatics. 2009;25(17):2281-2.

69. Larkin MA, Blackshields G, Brown NP, Chenna R, McGettigan PA, McWilliam H, Valentin F, Wallace IM, Wilm A, Lopez R, et al. Clustal W and Clustal X version 2.0. Bioinformatics. 2007;23(21):2947-8.

70. Tamura K, Stecher G, Peterson D, Filipski A, Kumar S. MEGA6: molecular evolutionary genetics analysis version 6.0. Mol Biol Evol. 2013;30(12):2725-9.

\section{Publisher's Note}

Springer Nature remains neutral with regard to jurisdictional claims in published maps and institutional affiliations.

Ready to submit your research? Choose BMC and benefit from:

- fast, convenient online submission

- thorough peer review by experienced researchers in your field

- rapid publication on acceptance

- support for research data, including large and complex data types

- gold Open Access which fosters wider collaboration and increased citations

- maximum visibility for your research: over $100 \mathrm{M}$ website views per year

At BMC, research is always in progress.

Learn more biomedcentral.com/submissions 